\title{
Comparative study of methodologies to determine the antioxidant capacity of Al-toxified blueberry amended with calcium sulfate
}

\author{
C. Meriño-Gergichevich ${ }^{1}$, G. Ondrasek ${ }^{2}$, M. Zovko ${ }^{2}$, D. Šamec ${ }^{3}$, M. Alberdi ${ }^{1,4}$, M. Reyes- \\ Díaz $^{1,4^{*}}$
}

${ }^{I}$ Center of Plant, Soil Interaction and Natural Resources Biotechnology, Scientific and Technological Bioresource Nucleus (BIOREN-UFRO), Universidad de La Frontera, Temuco, Chile. ${ }^{2}$ Department of Soil Amelioration, Faculty of Agriculture, University of Zagreb, Zagreb, Croatia. ${ }^{3}$ Department of Molecular Biology, Institute Ruđer Bošković, Zagreb, Croatia. ${ }^{4}$ Departamento de Ciencias Químicas y Recursos Naturales, Facultad de Ingeniería y Ciencias, Universidad de La Frontera, Temuco, Chile. ${ }^{*}$ Corresponding author:marjorie.reyes@ufrontera.cl

\begin{abstract}
Blueberry (Vaccinium corymbosum $\mathrm{L}$.) is well adapted to acidic soils where aluminum $\left(\mathrm{Al}^{3+}\right)$ can be linked to oxidative stress and antioxidant capacity $(\mathrm{AC})$. Calcium sulfate $\left(\mathrm{CaSO}_{4}\right)$ is used to alleviate $\mathrm{Al}^{3+}$ because it does not alter soil acidity. However, the role of Ca addition in AC, based on a single electron transfer reaction (SET), remains unknown. The aim was to evaluate the AC using SET methodologies, i.e., 2,2-diphenyl-2-picrylhydrazyl (DPPH), 2,2'-Azinobis-bis (3 ethylbenzothiazoline-6-sulphonic acid) (ABTS) and ferric reducing-antioxidant power (FRAP). Bueberry cultivars Elliot and Jersey were grown and exposed to the following treatments for 15 days: Control (nutrient solution alone, $\mathrm{pH} 4.5$ ); control $+\mathrm{Al}(\mathrm{Al})$; control $+\mathrm{Al}+\mathrm{Ca}(\mathrm{Al}+\mathrm{Ca})$ and control $+\mathrm{Ca}(\mathrm{Ca})$. The $\mathrm{Ca}$ and $\mathrm{Al}$ concentrations, total phenol (TP) content and radical scavenging activity (RSA) were evaluated at 7 and 15 days. The $\mathrm{Al}+\mathrm{Ca}$ and $\mathrm{Ca}$ treatments increased the $\mathrm{Ca}$ concentration in the leaves (22\%) and roots (40\%) of both cultivars compared with the control. The $\mathrm{Ca}$ in the tissues varied with cultivar and time. After 15 days, increases in TP, DPPH, ABTS and FRAP were detected. The cultivars showed positive relationships between the $\mathrm{TP}$ and $\mathrm{AC}$ in the leaves and roots. Thus, $\mathrm{CaSO}_{4}$ is an important tool to improve the $\mathrm{AC}$ in $\mathrm{Al}$-stressed fruit crops grown in acid soils.
\end{abstract}

Keywords: Aluminum, blueberry, calcium, SET assay 


\section{Introduction}

Great interest has been shown in highbush blueberry due to its high antioxidant capacity compared with other fruits (Howard et al., 2003; Dragović-Uzelac et al., 2010), which provides interesting potential benefits for human health (Heinonen, 2007). This capacity is attributed mainly to antioxidant phenolic compounds with important functions, such as free radical scavengers, hydrogen-donating compounds, singlet oxygen quenchers and/or metal ion chelators (Howard et al., 2003). The antioxidant capacity (AC) is associated with overcoming stresses caused by environmental factors, which may trigger an overproduction of reactive oxygen species (ROS) in plant cells (Yamamoto et al., 2002; Ma et al., 2007). Several studies have reported that enhanced $\mathrm{AC}$ is involved in the mitigation of oxidative stress in crop plants, improving their performance under the influence of this stressor. The antioxidant features depend on several factors such as cultivar, growing season, location and soil properties (Howard et al., 2003; Dragović-Uzelac et al., 2010).

Highbush blueberry is commonly cultivated in soils with a $\mathrm{pH}$ between 4.0 and 5.5; however, it is well known that in acidic soils, high amounts of toxic $\mathrm{Al}^{3+}$ can be released into the soil solution, damaging the roots and retarding shoot growth (Reyes-Díaz et al., 2011). This cation may be associated with ROS production, which induces oxidative stress in cell organelles (Yamamoto et al., 2002; Ma et al., 2007). To reduce $\mathrm{Al}^{3+}$ levels in the soil and reverse its harmful effect on plants, a common agricultural practice is to add a calcium amendment in the form of calcium sulfate $\left(\mathrm{CaSO}_{4}\right)$ (Takahashi et al., 2006). For plant species well adapted to acidity, such as blueberry, $\mathrm{CaSO}_{4}$ represents an optimal alternative because it does not alter soil pH (Meriño-Gergichevich et al., 2010; Reyes-Díaz et al., 2011). The effect of $\mathrm{CaSO}_{4}$ on biochemical features such as the antioxidant capacity of blueberry has been poorly studied. Reyes-Díaz et al., (2011) reported increases in nutrient content (especially $\mathrm{Ca}$ ) and reduction in $\mathrm{Al}$ concentrations in blueberry cultivars after the addition of $\mathrm{CaSO}_{4}$; a differential increase in the radical scavenging activity (RSA) in cultivars was also observed, concomitant with an increase in the $\mathrm{Al}$ concentration in the nutrient solution (100 and $200 \mu \mathrm{M})$.

Several analytical techniques have been used to estimate the antioxidant capacity of vegetables. Antioxidant capacity determination using 2,2-diphenyl1-picrylhydrazyl (DPPH), for example, is based on a single electron transfer (SET) reaction involving the redox reaction with the oxidant as an indicator of the reaction end point (Ban Lee Tan and Yan Lim, 2015; Georgieva and Mihaylova, 2015). Other SET reactions are used for RSA determination: i) ferric reducing ability of plasma (FRAP), where a ferric salt $\left(\mathrm{FeCl}_{3}\right)$ is used as an oxidant (Benzie and Strain, 1996); ii) 2,2'-azinobis(3-ethylbenzothiazoline-6-sulphonic acid) (ABTS), where $\mathrm{ABTS}^{+}$is the radical cation used for the assay (Re et al., 1999); and iii) The Folin-Ciocalteu method or total phenolics assay (Singleton and Rossi, 1965). However, these methodologies have shown different results for the same species and growing conditions. The aim of this study was to compare different methods for determining the antioxidant capacity of two blueberry cultivars exposed to $\mathrm{Al}^{3+}$ and ameliorated with $\mathrm{CaSO}_{4}$ at two evaluation times.

\section{Material and Methods}

\subsection{Plant material, growth conditions and treatments}

A controlled experiment was carried out in the growth chamber at the Faculty of Agriculture, University 
of Zagreb, Croatia. One-year-old plants of two blueberry cultivars (Elliot and Jersey), grown in a peat substrate, were used. The roots were carefully cleaned and washed using plenty of deionized water $(<1 \mu \mathrm{S})$. The plants were then placed into plastic pots (two plants per pot) filled with $2 \mathrm{~L}$ of continuously aerated and modified Hoagland's nutrient solution (Hoagland and Arnon, 1950) for conditioning during a 15-day period. After conditioning, the plants were grown in Hoagland's nutrient solution containing $5 \mathrm{mM} \mathrm{CaSO}_{4}(\mathrm{Ca})$ and/or $100 \mu \mathrm{M} \mathrm{AlCl}_{3}$ (Al) for 15 days. The treatments were: i) nutrient solution alone (Control); ii) Control $+\mathrm{Al}$; iii) Control $+\mathrm{Al}+\mathrm{Ca}$, and iv) Control+Ca. The $\mathrm{pH}$ was adjusted daily to $4.5 \mathrm{using}$ $0.1 \mathrm{M} \mathrm{HCl}$ and was measured using a high-accuracy portable $\mathrm{pH}$ meter (Milwaukee Instrument, Inc., Model SM 102, Rocky Mount, NC 27804, USA). The dissolved oxygen content in the nutrient solutions was also recorded on a daily basis using a portable meter (Mettler Toledo, SevenGo Pro). The growth chamber conditions were: $25 / 20^{\circ} \mathrm{C}$ day/night air temperature, $16 / 8 \mathrm{~h} \mathrm{light/dark} \mathrm{regime,} \mathrm{relative} \mathrm{air} \mathrm{humidity} 70 \%$, luminescence (Lux) 5,000 $\mathrm{lm} \mathrm{m} \mathrm{m}^{2}$ and the oxygen concentration in the nutrient solution was $7.6 \pm 0.5$ $\mathrm{mg} \mathrm{L}^{-1}$. On days 7 and 15 day of the experiment, the leaves and roots were harvested: one half was used for chemical (inorganic) analysis and the other half was stored at $-30{ }^{\circ} \mathrm{C}$ for biochemical analysis.

\subsection{Chemical analyses}

The leaves and roots of the plants were oven dried (for $24 \mathrm{~h}$ at $65^{\circ} \mathrm{C}$ in a Memmert model 410 , Schwabach, Germany) and then ground in a mill. The dried and ground samples were extracted with concentrated hydrochloric and nitric acids as well as hydrogen peroxide using the microwave technique in a CEM MARS Xpress microwave unit (CEM, Matthews, N.C.) for $\mathrm{Ca}, \mathrm{S}$ and $\mathrm{Al}$ determination using inductively coupled plasma optical emission spectrometry (ICPOES using a MPX AX; Varian, Perth, WA).

\subsection{Antioxidant capacity determination}

The antioxidant capacity of fresh leaf and root tissue was determined. The leaves were freeze-dried using a Lyovac GT 2 (Steris GmbH, Germany). The dried material $(30 \mathrm{mg})$ from the plants was frozen in liquid nitrogen $\left(-196{ }^{\circ} \mathrm{C}\right)$, powdered in a mortar, and homogenized with $1 \mathrm{~mL}$ of $80 \%$ methanol (v/v). The extracts were incubated in an ultrasonic bath for $15 \mathrm{~min}$, shaken for $2 \mathrm{~h}$ on a rotation homogenizer at $15 \mathrm{rpm}$, and then centrifuged at $10,000 \mathrm{~g}$ for 15 min (Eppendorf centrifuge 5451C, Germany). The supernatant was recovered and used for analysis.

\subsubsection{Total phenol concentrations}

Total phenols (TP) were determined using the FolinCiocalteu reagent following the method of Slinkard and Singleton (1997). The absorbance of the samples was measured using a UV-VIS spectrophotometer at $765 \mathrm{~nm}$. The TP concentration was expressed as $\mu \mathrm{g}$ gallic acid equivalent (GAE) per $\mathrm{g}^{-1} \mathrm{DW}$.

\subsubsection{DPPH radical scavenging analyses}

The free radical scavenging capacity of the leaves and roots was determined according to the procedure using the stable DPPH radical (Brand-Williams et al., 1995).

\subsubsection{ABTS ${ }^{+}{ }^{+}$radical scavenging capacity}

The radical scavenging capacity of tissue extracts was evaluated using the ABTS method according to Re et al. (1999). This method is based on the ability of antioxidant molecules to decolorize the radical 
cation $\mathrm{ABTS}^{+}{ }^{+}$, a blue-green chromophore with characteristic absorption at $734 \mathrm{~nm}$.

\subsubsection{FRAP assay}

The FRAP assay was conducted according to Benzie and Strain (1996). This method is based on an increase in the absorbance at $593 \mathrm{~nm}$ due to the formation of tri-pyridyl-S-triazine complexes with $\mathrm{Fe}^{2+}$ [TPTZ-Fe (II)] in the presence of a reducing agent.

\subsection{Experimental design and statistical analyses}

The experimental design corresponded to a factorial split-plot with six replicates. A two-way analysis of variance (ANOVA) test was used, with cultivars and treatment as the factors. All data passed the normality and equal variance tests after the KolmogorovSmirnov test. For the comparison of values with significant differences, a Tukey test was conducted at a significance level of $P \leq 0.05$. All statistical analyses were performed using Sigma Stat 3.1 (SPSS ${ }^{\circledR}$ Inc., Chicago, IL, USA).

\section{Results}

\subsection{Calcium and aluminum concentration in tissues}

The $\mathrm{Ca}$ treatment significantly increased the $\mathrm{Ca}$ concentration in the leaves of both cultivars (up to $40 \%$ ) at 7 and 15 days in comparison with the control, whereas in plants subjected to the $\mathrm{Al}+\mathrm{Ca}$ treatment, an increase in the Ca concentration was observed in the Elliot (30\%) and Jersey (21\%) cultivars for the same periods $(P \leq 0.05$; Table 1$)$. The $\mathrm{S}$ concentration in the leaves of Elliot was $30 \%$ and $35 \%$ higher in the $\mathrm{Al}+\mathrm{Ca}$ and $\mathrm{Ca}$ treatments, respectively, compared with the control at 7 days (data not shown). In both cultivars, the highest foliar Al concentration in comparison to the control was observed in the $\mathrm{Al}$ and $\mathrm{Al}+\mathrm{Ca}$ treatments at 15 days $(45 \%)(P \leq 0.001$; Table 1). In Jersey roots, the $\mathrm{Ca}$ treatment increased the $\mathrm{Ca}$ concentration by up to $22 \%$ in comparison with the control at 15 days $(P \leq 0.05)$. However, no significant increase in the amount of $\mathrm{Ca}$ was observed in comparison with the control in both cultivars exposed to the combined treatment $(\mathrm{Al}+\mathrm{Ca})$. Nonetheless, in the $\mathrm{Al}$ treatment, a statistically significant decrease in the Ca concentration was found in both cultivars compared with the control at 7 and 15 days (Table 1). The highest increase in the Al concentration in the roots of both cultivars was observed in the $\mathrm{Al}$ treatment followed by $\mathrm{A} 1+\mathrm{Ca}(P \leq 0.001$; Table 1$)$. The $\mathrm{S}$ concentration in the roots of Elliot subjected to $\mathrm{Al}+\mathrm{Ca}$ did not increase significantly at either time period in comparison with the control (data not shown).

\subsection{Total phenols}

The TPs in Elliot leaves were $70 \%$ lower in all treatments in comparison with the control at 7 days ( $P \leq 0.05$; Figure 1). By contrast, Jersey leaves exhibited up to a two fold increase in TPs in the Al and $\mathrm{Al}+\mathrm{Ca}$ treatments compared with the control $(P \leq 0.05)$. After 15 days of treatment application, a strong increase in TPs was observed in the $\mathrm{Al}+\mathrm{Ca}$ treatment in the leaves of both cultivars in comparison with the control $(P \leq 0.05)$. In the roots, the TPs exhibited a $\sim 20 \%$ increase in Elliot grown with $\mathrm{Al}$ and $\mathrm{Al}+\mathrm{Ca}$ compared with the control at 7 days, whereas this increase in Jersey plants was found only in the $\mathrm{Al}+\mathrm{Ca}$ treatment $(P=0.028)$. After 15 days of treatment application, the TPs in Elliot roots increased significantly $(43 \% ; P \leq 0.001)$ with Al treatment; however, the TPs in Jersey roots decreased by $31 \%$ in comparison with the control $(P=0.008)$. 
Table 1. The effect of $\mathrm{Al}$ and $\mathrm{CaSO}_{4}$ treatments on the $\mathrm{Ca}$ and $\mathrm{Al}$ content $\left(\mathrm{mg} \mathrm{g}^{-1} \mathrm{DW}\right)$ in the leaves and roots of two blueberry cultivars at two evaluation times. Each value represents the mean of six replicates. Different lowercase letters indicate statistically significant differences $(P \leq 0.05)$ between treatments for the same cultivar and exposure time.

\begin{tabular}{|c|c|c|c|c|c|c|c|c|c|}
\hline \multirow[t]{2}{*}{ Organ } & \multirow{2}{*}{$\begin{array}{c}\text { Content } \\
\mathrm{mg} \mathrm{g}^{-1} \\
\mathrm{DW}\end{array}$} & \multicolumn{4}{|c|}{ Elliot } & \multicolumn{4}{|c|}{ Jersey } \\
\hline & & Control & $\mathrm{Al}$ & $\mathrm{Al}+\mathrm{Ca}$ & $\mathrm{Ca}$ & Control & $\mathrm{Al}$ & $\mathrm{Al}+\mathrm{Ca}$ & $\mathrm{Ca}$ \\
\hline Leaves & $\begin{array}{l}\mathrm{Ca} \\
\mathrm{Al}\end{array}$ & $\begin{array}{l}6.55 \pm 0.38 \mathrm{~b} \\
0.012 \pm 0.0003 \mathrm{~b}\end{array}$ & $\begin{array}{l}7.14 \pm 0.91 \mathrm{~b} \\
0.016 \pm 0.0002 \mathrm{a}\end{array}$ & $\begin{array}{l}7.18 \pm 0.24 \mathrm{~b} \\
0.019 \pm 0.0001 \mathrm{a}\end{array}$ & $\begin{array}{l}1^{\text {st }} \text { san } \\
8.66 \pm 0.17 \mathrm{a} \\
0.013 \pm 0.0002 \mathrm{~b}\end{array}$ & $\begin{array}{l}\text { Ing } \\
5.94 \pm 0.16 \mathrm{~b} \\
0.010 \pm 0.0007 \mathrm{a}\end{array}$ & $\begin{array}{l}5.28 \pm 0.26 \mathrm{c} \\
0.011 \pm 0.0002 \mathrm{a}\end{array}$ & $\begin{array}{l}6.50 \pm 0.28 \mathrm{~b} \\
0.011 \pm 0.0003 \mathrm{a}\end{array}$ & $\begin{array}{l}9.28 \pm 0.40 \mathrm{a} \\
0.010 \pm 0.0003 \mathrm{a}\end{array}$ \\
\hline Leaves & $\begin{array}{l}\mathrm{Ca} \\
\mathrm{Al}\end{array}$ & $\begin{array}{l}7.15 \pm 0.14 c \\
0.012 \pm 0.0003 b\end{array}$ & $\begin{array}{l}8.32 \pm 0.20 \mathrm{c} \\
0.022 \pm 0.0002 \mathrm{a}\end{array}$ & $\begin{array}{l}10.7 \pm 0.23 \mathrm{~b} \\
0.019 \pm 0.0001 \mathrm{a}\end{array}$ & $\begin{array}{l}2^{\text {nd }} \text { san } \\
12.14 \pm 0.15 \mathrm{a} \\
0.012 \pm 0.0003 \mathrm{~b}\end{array}$ & $\begin{array}{l}\text { ing } \\
5.94 \pm 0.16 \mathrm{c} \\
0.011 \pm 0.0007 \mathrm{~b}\end{array}$ & $\begin{array}{l}4.48 \pm 0.27 \mathrm{~d} \\
0.015 \pm 0.0004 \mathrm{a}\end{array}$ & $\begin{array}{l}7.56 \pm 0.26 \mathrm{~b} \\
0.017 \pm 0.0008 \mathrm{a}\end{array}$ & $\begin{array}{l}9.30 \pm 0.40 \mathrm{a} \\
0.011 \pm 0.0002 \mathrm{~b}\end{array}$ \\
\hline Roots & $\begin{array}{l}\mathrm{Ca} \\
\mathrm{Al}\end{array}$ & $\begin{array}{l}7.00 \pm 0.16 \mathrm{ab} \\
0.16 \pm 0.02 \mathrm{c}\end{array}$ & $\begin{array}{l}3.95 \pm 0.28 \mathrm{c} \\
1.12 \pm 0.04 \mathrm{a}\end{array}$ & $\begin{array}{l}6.47 \pm 0.26 \mathrm{~b} \\
0.72 \pm 0.02 \mathrm{~b}\end{array}$ & $\begin{array}{l}1^{\text {st }} \text { san } \\
7.49 \pm 0.22 \mathrm{a} \\
0.16 \pm 0.005 \mathrm{c}\end{array}$ & $\begin{array}{l}\text { ing } \\
6.46 \pm 0.32 \mathrm{a} \\
0.16 \pm 0.002 \mathrm{c}\end{array}$ & $\begin{array}{l}3.50 \pm 0.23 \mathrm{~b} \\
0.95 \pm 0.05 \mathrm{a}\end{array}$ & $\begin{array}{l}6.50 \pm 0.29 \mathrm{a} \\
0.64 \pm 0.09 \mathrm{~b}\end{array}$ & $\begin{array}{l}5.82 \pm 0.15 \mathrm{a} \\
0.13 \pm 0.012 \mathrm{c}\end{array}$ \\
\hline Roots & $\begin{array}{l}\mathrm{Ca} \\
\mathrm{Al}\end{array}$ & $\begin{array}{l}6.96 \pm 0.16 \mathrm{ab} \\
0.16 \pm 0.02 \mathrm{c}\end{array}$ & $\begin{array}{l}3.46 \pm 0.09 \mathrm{c} \\
0.71 \pm 0.06 \mathrm{a}\end{array}$ & $\begin{array}{l}6.22 \pm 0.24 b \\
0.46 \pm 0.02 b\end{array}$ & $\begin{array}{l}2^{\text {nd }} \text { sat } \\
7.17 \pm 0.28 \mathrm{a} \\
0.15 \pm 0.01 \mathrm{c}\end{array}$ & $\begin{array}{l}\text { ling } \\
6.44 \pm 0.32 \mathrm{~b} \\
0.15 \pm 0.002 \mathrm{~b}\end{array}$ & $\begin{array}{l}4.56 \pm 0.29 \mathrm{c} \\
0.62 \pm 0.05 \mathrm{a}\end{array}$ & $\begin{array}{l}4.48 \pm 0.15 \mathrm{c} \\
0.63 \pm 0.09 \mathrm{a}\end{array}$ & $\begin{array}{l}8.35 \pm 0.36 \mathrm{a} \\
0.12 \pm 0.012 \mathrm{~b}\end{array}$ \\
\hline
\end{tabular}

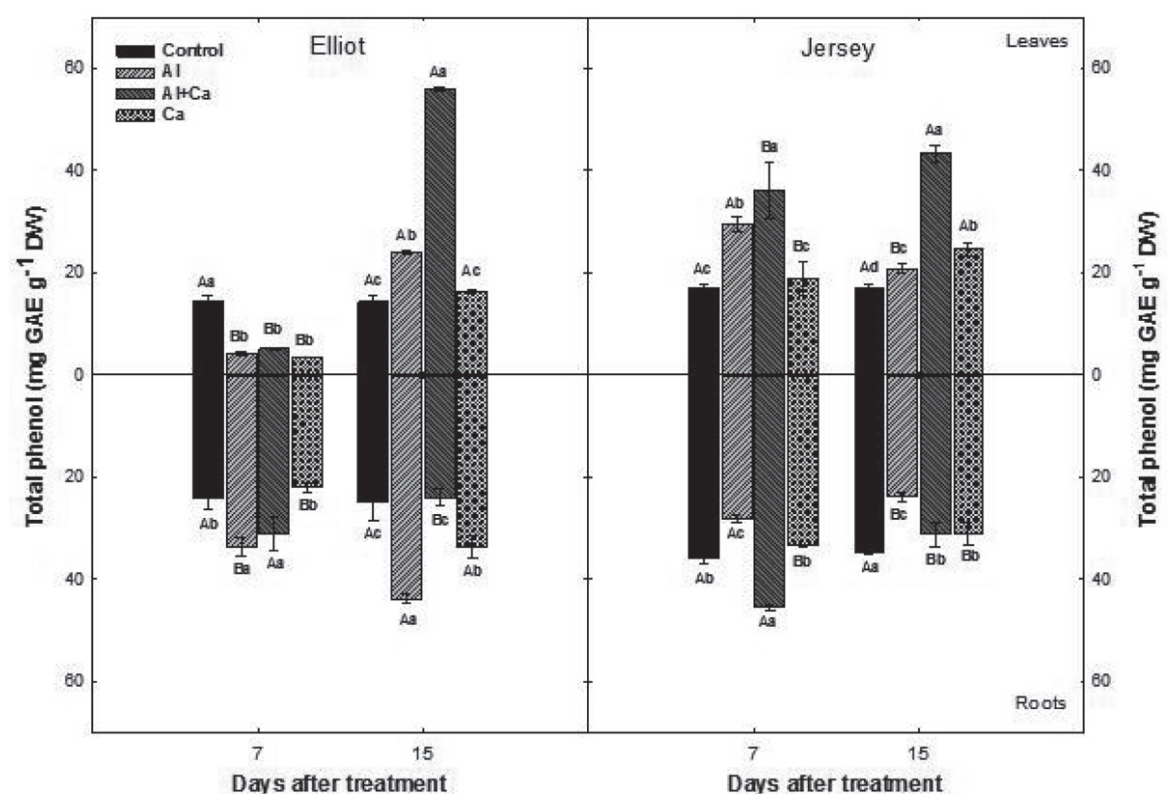

Figure 1. The effect of $\mathrm{Al}$ and $\mathrm{CaSO}_{4}$ treatments on changes in the total phenols in the leaves and roots of two blueberry cultivars during the $1^{\text {st }}$ ( 7 days after treatment) and $2^{\text {nd }}$ ( 15 days after treatment) sampling periods. Each value represents the mean of six replicates $( \pm$ S.E. $)$. Different lowercase letters indicate statistically significant differences $(P \leq 0.05)$ between treatments for the same cultivar and exposure time. Different uppercase letters show differences $(P \leq 0.05)$ between exposure times for the same cultivar and treatment. 


\subsection{Antioxidant capacity and reducing power}

The total antioxidant capacity (DPPH and ABTS assays) and reducing power (FRAP assay) of the two highbush blueberry cultivars are shown in Figures 2, 3 and 4, respectively. After 7 days of treatment application, DPPH, ABTS and FRAP methods showed a reduction in the antioxidant capacity of the leaves of Elliot, whereas Jersey exhibited an increase in antioxidant capacity and reducing power in response to the $\mathrm{Al}$ and $\mathrm{Al}+\mathrm{Ca}$ treatments in comparison with the control $(P \leq 0.001$; Figure 2). According to the results obtained at 15 days, Elliot showed an increase (approximately two fold) in antioxidant capacity in the $\mathrm{Ca}$ and $\mathrm{Al}+\mathrm{Ca}$ treatments compared with the control $(P \leq 0.001)$.

In comparison with the control, an increase in the foliar antioxidant capacity, measured using the ABTS method, was observed at 15 days in Elliot plants subjected to $\mathrm{Al}$ (2-fold) and $\mathrm{Al}+\mathrm{Ca}(3.8$-fold) treatments $(P \leq 0.001)$. An increase in the antioxidant capacity was detected in Jersey leaves at 7 days, which was only maintained through to 15 days in the $\mathrm{Al}+\mathrm{Ca}$ - treated plants. The ABTS assay did not show any significant difference between the applied treatments $(\mathrm{Ca}$ and $\mathrm{Al})$ and the control with respect to Elliot roots; however, in Jersey, the same parameter was significantly lower in plants treated with $\mathrm{Al}(\sim 50 \%)$ compared with the control (Figure 3).

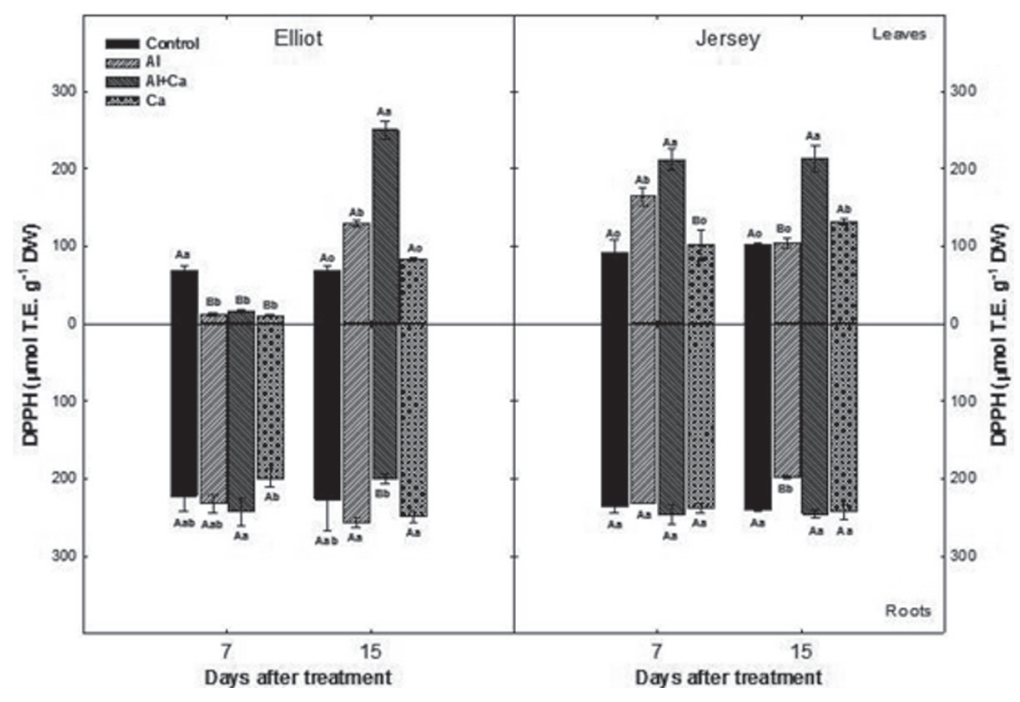

Figure 2. The effect of $\mathrm{Al}$ and $\mathrm{CaSO}_{4}$ treatments on the antioxidant capacity of the leaves and roots of two blueberry cultivars measured using DPPH methodology during the $1^{\text {st }}$ ( 7 days after treatment) and $2^{\text {nd }}$ (15 days after treatment) sampling periods. Each value represents the mean of six replicates ( \pm S.E.). Different lowercase letters indicate statistically significant differences $(P \leq 0.05)$ between treatments for the same cultivar and exposure time. Different uppercase letters show differences $(P \leq 0.05)$ between exposure times for the same cultivar and treatment. 
Similar to the DPPH and ABTS radical scavenging in the leaves at 7 days, decreased FRAP values were observed in $\mathrm{Al}$-, $\mathrm{Al}+\mathrm{Ca}$ - and Ca-treated Elliot plants $(P \leq 0.05)$, whereas in the same treatments, Jersey showed higher FRAP values than the control $(P \leq 0.001$; Figure 4$)$. The highest FRAP value in the leaves was found in the plants subjected to the $\mathrm{Al}+\mathrm{Ca}$ treatment, i.e., 4.5- and 2.3-fold increases compared with the control in Elliot and Jersey, respectively, at 15 days ( $P \leq 0.001$; Figure 4$)$. The FRAP values in the roots of Elliot increased significantly with the addition of $\mathrm{Al}$ (by $34 \%$ and $86 \%$ at 7 and 15 days, respectively) relative to the control. An increase of 57\% in the FRAP value was found in Elliot roots subjected to Ca compared the control at 15 days $(P \leq 0.05)$, while in Jersey, no changes were observed in the FRAP value during either time period (Figure 4).

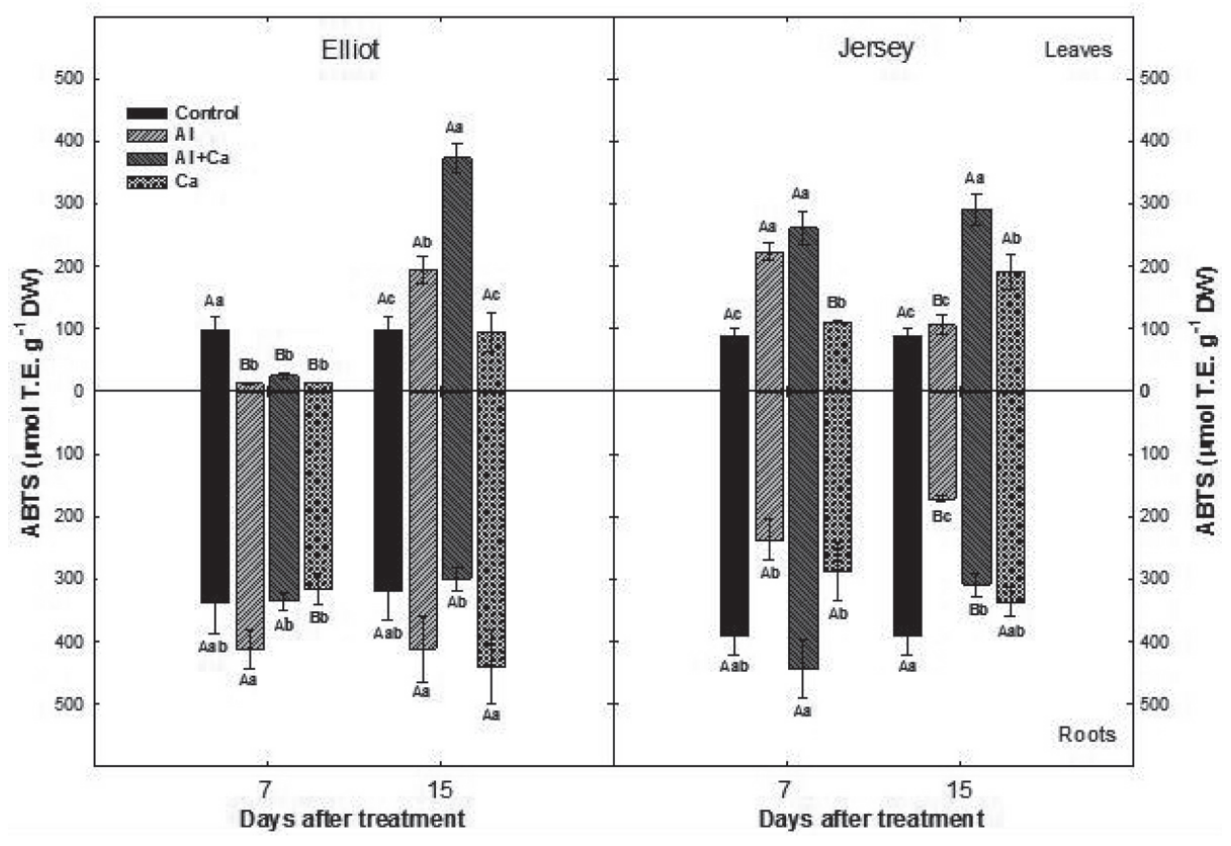

Figure 3. The effect of $\mathrm{Al}$ and $\mathrm{CaSO}_{4}$ treatments on the antioxidant capacity of the leaves and roots of two blueberry cultivars measured using ABTS methodology during the $1^{\text {st }}$ ( 7 days after treatment) and $2^{\text {nd }}$ (15 days after treatment) sampling periods. Each value represents the mean of six replicates ( \pm S.E.). Different lowercase letters indicate statistically significant differences $(P \leq 0.05)$ between treatments for the same cultivar and exposure time. Different uppercase letters show differences $(P \leq 0.05)$ between exposure times for the same cultivar and treatment. 


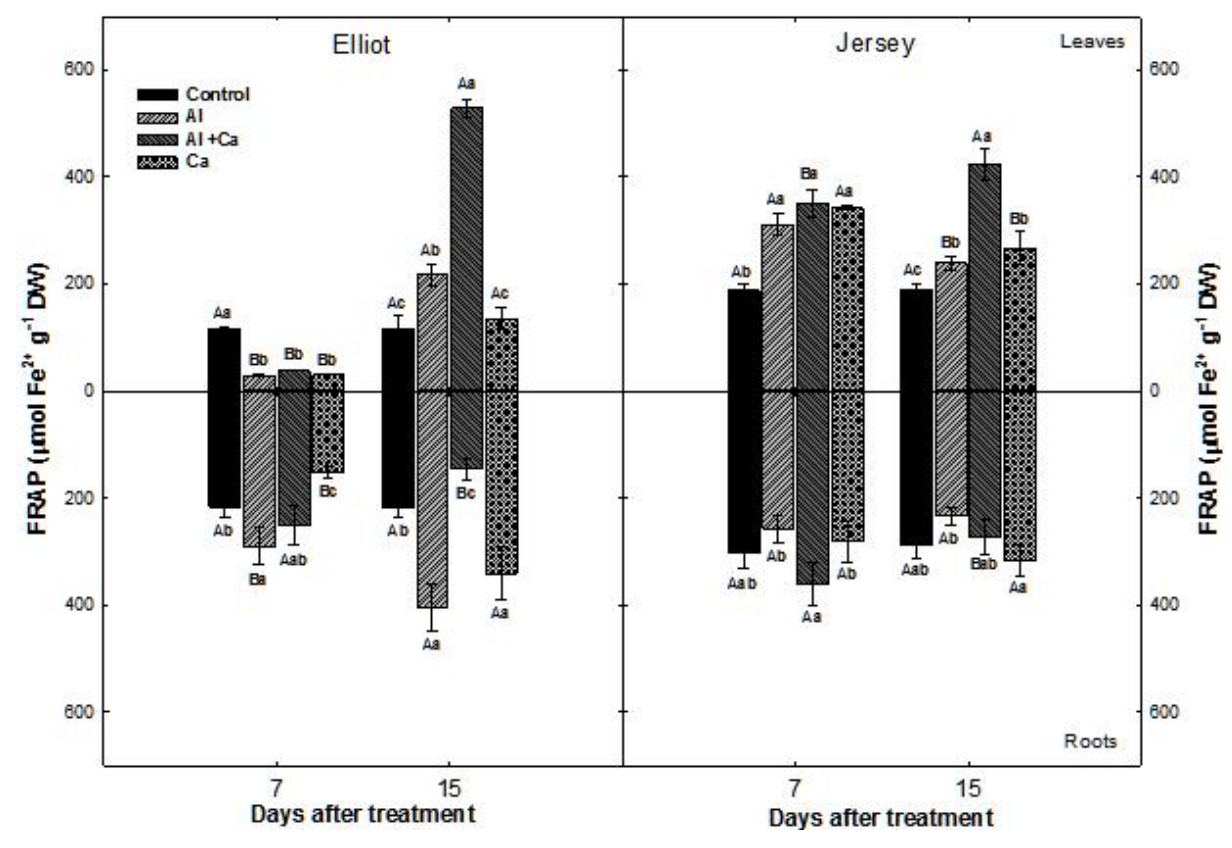

Figure 4. The effect of $\mathrm{Al}$ and $\mathrm{CaSO}_{4}$ treatments on the antioxidant capacity of the leaves and roots of two blueberry cultivars measured using FRAP methodology during the $1^{\text {st }}\left(7\right.$ days after treatment) and $2^{\text {nd }}$ (15 days after treatment) sampling periods. Each value represents the mean of six replicates ( \pm S.E.). Different lowercase letters indicate statistically significant differences $(P \leq 0.05)$ between treatments for the same cultivar and exposure time. Different uppercase letters show differences $(P \leq 0.05)$ between exposure times for the same cultivar and treatment.

\section{Discussion}

It has been reported that under acidic $(\mathrm{pH} \leq 5.5)$ conditions, significant correlations between low $\mathrm{pH}$ and high $\mathrm{Al}^{3+}$ (at micromolar concentrations) exhibit phytotoxic effects in many cultivated plants (Foy, 1998). In blueberry, which is well adapted to acidic soils with generally low $\mathrm{Ca}$ levels, $\mathrm{Al}^{3+}$ can exert a considerable negative influence on biochemical and physiological parameters, as well as plant vigor. This can lead to dieback or death, particularly in young plants, due to the accumulation of $\mathrm{Al}$ in tissues (Reyes Díaz et al., 2010). In our study, a reduction in $\mathrm{Al}$ uptake by roots was observed in the $\mathrm{Al}+\mathrm{Ca}$ treatment in comparison with the plants subjected to $\mathrm{Al}$ alone (Table 1). The foliar $\mathrm{Al}$ contents (0.01$\left.0.02 \mathrm{mg} \mathrm{g}^{-1} \mathrm{DW}\right)$ in the plants exposed to the $\mathrm{Al}+\mathrm{Ca}$ treatment were lower than the range of 0.08 and 0.15 $\mathrm{mg} \mathrm{g}^{-1}$ DW reported by Reyes-Díaz et al. (2011) for blueberry. Based on the negative correlations found between the $\mathrm{Ca}$ and $\mathrm{Al}$ concentrations in Elliot roots at 7 days $(\mathrm{r}=-0.71, P=0.009)$ and 15 days $(\mathrm{r}=-0.70$, $P=0.01$ ), the reduction in the $\mathrm{Al}$ concentration would indicate mainly that competitive activity between calcium and aluminum in the roots was the result of the ameliorative role of $\mathrm{CaSO}_{4}$. Yang et al. (1996) 
reported that in plants of the blueberry cultivar Elliot, Ca uptake was negatively affected by influx inhibition and by the blocking of Ca-specific ion channels in root cells due to its competition with $\mathrm{Al}$ for essential binding sites in the root apoplast. Furthermore, $\mathrm{Al}$ can be excluded from roots by the formation of an outer sphere complex with $\mathrm{SO}_{4}^{2-}$ (Alva et al., 1991). Similar correlations were not found for Jersey, however, suggesting that genotypes within species can differ in their ability to tolerate or resist $\mathrm{Al}^{3+}$ by external or internal mechanisms (Foy, 1988). Although $\mathrm{CaSO}_{4}$ soil amendment has been used as a Ca source and to ameliorate the toxic effects of $\mathrm{Al}^{3+}$ in acidic environments (Takahashi et al., 2006), the effect of its application to berry plants has scarcely been reported, considering the multiple roles of $\mathrm{Ca}$ nutrition in response to environmental stress such as antioxidant performance. The control plants of the two cultivars evaluated showed similar $\mathrm{Ca}$ concentrations in the leaves and roots (6-7 $\left.\mathrm{mg} \mathrm{g}^{-1} \mathrm{DW}\right)$, whereas the $\mathrm{CaSO}_{4}^{-}$ treated plants had higher $\mathrm{Ca}$ concentration (up to $\sim 12$ $\mathrm{mg} \mathrm{g}^{-1} \mathrm{DW}$ in the leaves of Elliot) than those reported previously for blueberries by Starast et al. (2007) who considered that healthy bushes could contain 3 to 8 $\mathrm{mg} \mathrm{g}^{-1} \mathrm{DW}$ of foliar $\mathrm{Ca}$.

It has been reported in the literature that $\mathrm{Al}^{3+}$ triggers oxidative stress by increasing ROS generation in cell organelles, which activates enzymatic and nonenzymatic antioxidant responses (Yamamoto et al., 2002). In particular, phenolics have an optimal chemical structure for radical scavenging activity due to their considerable ability to act as hydrogen or electron donors and to chelate transitional ion metals (Huang et al., 2005; Oroian and Escriche, 2015). The biosynthesis of phenol compounds is considered to be responsible for the antioxidant capacity of blueberry (Piljac-Žegarac et al., 2009) and their concentration can be linked to the availability of nutrients such as
N, P and Ca (Steward et al., 2001). Increased TPs in Jersey leaves at 7 days, especially in the $\mathrm{Al}+\mathrm{Ca}$ treatment, suggest that phenol synthesis is stimulated by $\mathrm{Ca}$ content ( $\mathrm{r}=0.70, P=0.01)$ (Table 2$)$. In Elliot, however, a negative correlation was found for the same period ( $\mathrm{r}=-0.73 ; P \leq 0.01)$. Heinonen (2007) reviewed the genetic and environmental factors that could affect phenolic composition in blueberry plant tissues. In the roots of Elliot (at 7 and 15 days) and Jersey (at 7 days), TP was negatively correlated with the Ca content (Table 2). In experiments carried out on blueberry plants supplemented with $\mathrm{Ca}$ and boron (B) fertilizers, Eichholz et al. (2011) and Howard et al. (2003) suggested that excessive Ca content and varietal factors could be related to polyphenol synthesis. Wang and Shao (2006) indicated that oxidative stress and antioxidant systems are linked with $\mathrm{Ca}^{2+}$ and calmodulin proteins, which improve the ability of the plant to tolerate stress and therefore enhance the activity of their antioxidant systems. On the other hand, the $\mathrm{Al}$ treatment in our study was linked to leaf TPs in Jersey at 15 days $(\mathrm{r}=0.64 ; P=$ 0.02 ) (Table 2). Root TPs were highly correlated with $\mathrm{Al}$ in Elliot and Jersey at 7 days $(\mathrm{r}=0.91 ; P \leq 0.001$ and $\mathrm{r}=0.83 ; P \leq 0.001$, respectively) (Table 2). However, at 15 days, this relationship was not observed in Elliot, while it was negative in Jersey $(\mathrm{r}=-0.60 ; P=$ 0.04 ), indicating the activation of other resistance mechanisms, including antioxidant enzymes.

The strong relationship between the phenolic content and antioxidant capacity in blueberry has been well documented (Howard et al., 2003). Our findings show strong positive correlations between the TP and RSA measured in the leaves and roots using the DPPH and ABTS methodologies (Table 3), similar to the reports for leaves of black currant (Ribes nigrum L.; Tabart et al., 2007), Jerusalem artichoke (Helianthus tuberosus L.; Yuan et al., 2012), blueberry (Pervin et al., 2013) 
and Origanum vulgare leaves (Majeed et al., 2015). The leaves of the two cultivars studied here exhibited greater increases in antioxidant activity in the $\mathrm{Al}+\mathrm{Ca}$ treatment compared with the control, particularly at 15 days, based on the DPPH and ABTS methodologies $(P \leq 0.05)$. However, Elliot did not show high DPPH or ABTS antioxidant capacity in the leaves at 7 days, suggesting that some other mechanisms (e.g., enzymatic antioxidants) were activated to prevent the harmful effects of $\mathrm{Al}^{3+}$. A previous report from ReyesDíaz et al. (2011) documented higher antioxidant activity (up to $100 \%$ compared with the control) in the leaves of blueberry subjected to $100 \mu \mathrm{M} \mathrm{Al}$ plus $5 \mathrm{mM}$ $\mathrm{CaSO}_{4}$ for 15 days, measured using DPPH. Pervin et al. (2013) recently observed that blueberry leaf extract showed higher scavenging properties when assayed using ABTS compared with DPPH radicals in comparison with a standard (ascorbic acid). There is very little information on comparative studies of the root-scavenging capacity of blueberry grown in the presence of phytotoxic $\mathrm{Al}^{3+}$ with the application of $\mathrm{CaSO}_{4}$ to ameliorate the deleterious effects of this cation. In the roots of the blueberry cultivars Legacy and Bluegold, treatment with $100 \mu \mathrm{M} \mathrm{Al}$ increased the antioxidant activity (measured using DPPH) between $30-100 \%$ compared with untreated plants after 7 days (Reyes-Díaz et al., 2010). In contrast, the scavenging capacity of Legacy was only $\sim 30 \%$ higher than the control after 14 days. In our experiment, Jersey plants grown in $100 \mu \mathrm{M} \mathrm{Al}$ showed lower ABTS $(\sim 40 \%)$ in the roots at 7 days, which increased to $60 \%$ at 15 days relative to the control. Nonetheless, the DPPH methodology only showed a minimal reduction in the RSA in the $100 \mu \mathrm{M}$ Al treatment at 15 days. Interestingly, we found a significant positive (approximately $\mathrm{r}=0.80$ ) relationship between the root $\mathrm{Ca}$ content and antioxidant activity of Jersey, but not Elliot (evaluated using DPPH and ABTS).
An interesting positive correlation was found between the $\mathrm{Al}$ concentration and ABTS in roots for both evaluation times and cultivars. Although the antioxidant capacities of plant extracts varied between the two assay methods, these results show that the blueberry leaves and roots from the selected cultivars presented different responses to supplemental $\mathrm{Ca}$ and $\mathrm{Al}$ under variable evaluation times.

The reducing power measured using the FRAP assay is generally linked to the presence of reducing substances. These substances donate hydrogen protons to free radicals and thereby break their chains and destabilize those (Huang et al., 2005). They may thus serve as a significant indicator of antioxidant capacity in different plant species (Pervin et al., 2013). In this study, the leaf FRAP in all treatments showed a lower capacity in Elliot compared with the control (Figure 4). In the roots of Elliot plants, Al toxicity significantly increased FRAP at both evaluation times and was significantly correlated with $\mathrm{TP}(\mathrm{r}=0.94)$ and DPPH $(\mathrm{r}=0.69)$ at 7 days (Table 2). This suggests that for this cultivar, the roots possess a more pronounced antioxidant mechanism against toxic $\mathrm{Al}^{3+}$. Subsequently, the correlation coefficients between FRAP and TP $(r=0.87)$, DPPH $(r=0.75)$ and ABTS $(r=0.65)$ indicated that phenolics make a greater contribution to the reducing power (Table 3). Moreover, Jersey showed a significantly higher FRAP capacity in the leaves compared with the control at both sampling points, which was probably influenced by the vitamin $\mathrm{C}$ content according to Guo et al. (2003) and Pervin et al. (2013).

In conclusion, the addition of $\mathrm{CaSO}_{4}$ to blueberry induced an increase in the $\mathrm{Ca}$ concentration, particularly in the leaves, and this effect varied between the two varieties. This approach can be considered in the management of highbush blueberry grown under acidic soil conditions and in the 
presence of toxic $\mathrm{Al}^{3+}$ levels because the uptake of $\mathrm{Al}^{3+}$ was reduced by the application of $\mathrm{CaSO}_{4}$. The $\mathrm{Ca}$ concentration was negatively related to the total phenols in the leaves of Elliot at the first evaluation point, but not in Jersey at either sampling point. In the roots, the increased $\mathrm{Ca}$ concentration favored the antioxidant activity in Jersey, although this effect was not rapid. This study showed evidence for the effect of $\mathrm{Al}^{3+}$ on the biosynthesis of phenolic compounds and radical scavenging activity in roots, but only at 7 days. Both leaf and root phenols were correlated with the antioxidant capacity assayed using different methodologies such as DPPH, ABTS and FRAP. The results obtained for the antioxidant assays demonstrated that these methodologies can be used to evaluate the antioxidant capacity of blueberry. However, the DPPH methodology showed the strongest relationship with the concentration of non-enzymatic antioxidant compounds in both of the organs and cultivars evaluated. Finally, this work demonstrated that $\mathrm{CaSO}_{4}$ application could be an important tool for mitigating the harmful effect of toxic $\mathrm{Al}^{3+}$ by improving the antioxidant performance of fruit crops established under stressed conditions.

Table 2. Correlation coefficients indicating the relationship between foliar $\mathrm{Ca}$ and $\mathrm{Al}$ with the total phenols (TPs), antioxidant capacity (DPPH, ABTS) and reducing power (FRAP) of the leaves and roots of blueberry cultivars 7 days ( $\left(1^{\text {st }}\right.$ sampling) and 15 days $\left(2^{\text {nd }}\right.$ sampling $)$ after $\mathrm{Al}$ and $\mathrm{CaSO}_{4}$ treatment. Values are the average of six replicates.

\begin{tabular}{|c|c|c|c|c|c|c|c|c|c|}
\hline \multirow[t]{2}{*}{ Cultivar } & & \multicolumn{4}{|c|}{$\begin{array}{l}\text { 7-days after } \\
\text { treatment }\end{array}$} & \multicolumn{4}{|c|}{$\begin{array}{c}\text { 15-days after } \\
\text { treatment }\end{array}$} \\
\hline & & $\mathrm{TP}$ & DPPH & FRAP & ABTS & TP & DPPH & FRAP & ABTS \\
\hline \multicolumn{10}{|l|}{ Elliot } \\
\hline \multirow[t]{2}{*}{ Leaves } & $\mathrm{Ca}$ & $-0.73 * *$ & $-0.63^{*}$ & 0.16 & 0.39 & 0.05 & 0.09 & 0.05 & 0.10 \\
\hline & $\mathrm{Al}$ & 0.17 & 0.20 & 0.14 & 0.06 & 0.19 & 0.20 & 0.20 & 0.37 \\
\hline \multirow[t]{2}{*}{ Roots } & $\mathrm{Ca}$ & $-0.81^{* *}$ & 0.39 & $-0.77 * *$ & $-0.76^{* *}$ & $-0.64 *$ & 0.28 & 0.44 & 0.03 \\
\hline & $\mathrm{Al}$ & $0.91 * * *$ & $0.70 * *$ & $0.88^{* * *}$ & $0.60^{*}$ & 0.38 & 0.10 & 0.02 & 0.10 \\
\hline \multicolumn{10}{|l|}{ Jersey } \\
\hline \multirow[t]{2}{*}{ Leaves } & $\mathrm{Ca}$ & $0.70 * *$ & $-0.60 *$ & 0.08 & $-0.64 *$ & $0.69^{*}$ & $0.73 * *$ & $0.71 * *$ & $0.80 * *$ \\
\hline & $\mathrm{Al}$ & 0.13 & 0.11 & $-0.58^{*}$ & 0.14 & $0.64 *$ & $0.60 *$ & $0.65^{*}$ & 0.53 \\
\hline \multirow[t]{2}{*}{ Roots } & $\mathrm{Ca}$ & $-0.62^{*}$ & 0.25 & 0.46 & 0.23 & 0.54 & $0.80^{* *}$ & $0.77 * *$ & $0.78 * *$ \\
\hline & $\mathrm{Al}$ & $0.83 * * *$ & 0.49 & $0.88^{* * *}$ & $0.76^{* *}$ & $-0.60 *$ & 0.46 & $-0.72 * *$ & $-0.69 *$ \\
\hline
\end{tabular}

Significance designated as $* P \leq 0.05 ; * * \mathrm{P} \leq 0.01 ; * * * P \leq 0.001$. 
Table 3. Correlation coefficients between the total phenolic content and antioxidant capacity (DPPH, ABTS) and reducing power (FRAP) of the leaves and roots of blueberry cultivars 7 days ( $1^{\text {st }}$ sampling) and 15 days ( $2^{\text {nd }}$ sampling) after $\mathrm{Al}$ and $\mathrm{CaSO}_{4}$ treatment. Values are the average of six replicates.

\begin{tabular}{|c|c|c|c|c|c|c|c|}
\hline \multirow[t]{2}{*}{ Cultivar } & & \multicolumn{3}{|c|}{$\begin{array}{l}\text { 7-days } \\
\text { after } \\
\text { treatment }\end{array}$} & \multicolumn{3}{|c|}{$\begin{array}{l}\text { 15-days } \\
\text { after } \\
\text { treatment }\end{array}$} \\
\hline & & DPPH & ABTS & FRAP & DPPH & ABTS & FRAP \\
\hline \multicolumn{8}{|l|}{ Elliot } \\
\hline Leaves & TP & $0.91 * * *$ & $0.73 * *$ & $0.69^{*}$ & $0.99 * * *$ & $0.96^{* * *}$ & $0.97 * * *$ \\
\hline Roots & $\mathrm{TP}$ & $0.72 * *$ & 0.57 & $0.94 * * *$ & $0.78 * *$ & $0.65^{*}$ & $0.87 * * *$ \\
\hline \multicolumn{8}{|l|}{ Jersey } \\
\hline Leaves & $\mathrm{TP}$ & $0.97 * * *$ & $0.97 * * *$ & $0.67^{*}$ & $0.99 * * *$ & $0.92 * * *$ & $0.98 * * *$ \\
\hline Roots & TP & $0.66^{*}$ & $0.78^{* *}$ & $0.83 * * *$ & $0.84 * * *$ & $0.88^{* * *}$ & $0.62 *$ \\
\hline
\end{tabular}

Significance designated as $* P \leq 0.05 ; * * \mathrm{P} \leq 0.01 ; * * * P \leq 0.001$.

\section{Acknowledgements}

C. Meriño-Gergichevich thanks to FONDECYT $\mathrm{N}^{\mathrm{o}}$ 3140622. We are grateful to the International Relations Office and Department of Soil Amelioration in the Faculty of Agriculture, University of Zagreb and the Department of Molecular Biology at the Institute Ruđer Bošković, and Hellea Ltd. (Zagreb, Croatia) for providing highbush blueberry transplants. The authors would also like to thank FONDECYT N ${ }^{\circ}$ 11080231".

\section{References}

Ban Lee Tan, J., Yan lim, Y. 2015. Critical analysis of current methods for assessing the in vitro antioxidant and antibacterial activity of plant extracts. Food Chem. 172, 814-822.

Benzie, I.F., Strain, J.J. 1996. The ferric reducing ability of plasma (FRAP) as a measure of 'antioxidant power': the FRAP assay. Anal. Biochem. 239, 70-76.
Brand-Williams, W., Cuvelier, M.E., Berset, C. 1995. Use of a free radical method to evaluate antioxidant activity. Lebensmittel-Wissenschaft und-Technologie. 28, 25-30.

Chinnici, F., Bendini, A.A., Gaiani, A., Riponi C. 2004. Radical scavenging activities of peels and pulps from cv. Golden delicious apples as related to their phenolic composition. J. Agr. Food Chem. 52, 4684-4689.

Dragović-Uzelac, V., Savić, Z., Brala, A., Levaj, B., Bursać-Kovačević, D., Biško, A. 2010. Evaluation of phenolic content and antioxidant capacity of blueberry cultivars (Vaccinium corymbosum L.) grown in the northwest Croatia. Food Technol. Biotechnol. 48, 74-27.

Eichholz, I., Huykens-Keil, S., Kroh, L.W., Rohn, S. 2011. Phenolic compounds, pectin and antioxidant activity in blueberries (Vaccinium corymbosum L.) influenced by boron and mulch cover. J. Appl. Bot. Food. Qual. 84, 26-32. 
Foy, C.D. 1988. Plant adaptation to acid, aluminumtoxic soils. Commun. Soil Sci. Plan. 19, 959-987.

Georgieva, L., Mihaylova, D. 2015. Screening of total phenolic content and radical scavenging capacity of Bulgarian plant species. Int. Food Res. J. 22, 240-245.

Guo, C., Yang, J., Wei, J., Li, Y., Xu, J., Jiang, Y. 2003. Antioxidant activities of peel, pulp and seed fractions of common fruits as determined by FRAP assay. Nutr. Res. 23, 1719-1726.

Heinonen, M. 2007. Antioxidant activity and antimicrobial effect of berry phenolics -A finnish perspective. Mol. Nutr. Food Res. 51, 684-691.

Hoagland, D.R., Arnon, D.I. 1950. Water-culture method for growing plants without soil. Calif Agric Exp. Stn. Circ. 347, University of California, Berkeley, CA.

Howard, L.R., Clark, J.R., Brownmiller, C. 2003. Antioxidant capacity and phenolic content in blueberries as affected by genotype and growing season. J. Sci. Food Agric. 83, 1238-1247.

Huang, D., Ou, B., Prior, R.L. 2005. The chemistry behind antioxidant capacity assays. J. Agric. Food Chem. 53, 1841-1856.

Ma, B., Wan, J., Shen, Z. 2007. $\mathrm{H}_{2} \mathrm{O}_{2}$ production and antioxidant responses in seeds and early seedlings of two different rice varieties exposed to aluminum. J. Plant Growth Regul. 52, 91-100.

Majeed, M., Hussain, A.I., Chatha, S.A.S., Khosa, M.K.K., Kamal, G.M., Kamal, M.A., Zhang, X., Liu, M. 2015. Optimization protocol for the extraction of antioxidant components from Origanum vulgare leaves using response surface methodology. Saudi J. Biol. Sci. (in press).
Meriño-Gergichevich, C., Alberdi, M., Ivanov, A. G., Reyes-Díaz, M. 2010. $\mathrm{Al}^{3+}-\mathrm{Ca}^{2+}$ interaction in plants growing in acid soils: Al-phytotoxicity response to calcareous amendments. J. Soil. Sci. Plant Nutr. 10, 217-243.

Oroian, M., Escriche, I. 2015. Antioxidants: Characterization, natural sources, extraction and analysis. Food Res. Int. 74, 10-36.

Pervin, M., Hasnat, Md A., Lim, B. O. 2013. Antibacterial and antioxidant activities of Vaccinium corymbosum L. leaf extract. Asian Pac. J. Trop. Dis. 3, 444-453.

Piljac-Žegarac, J., Belščak, A., Piljac, A. 2009. Antioxidant capacity and polyphenolic content of blueberry (Vaccinium corymbosum L.) leaf infusions. J. Med. Food. 12, 1-7.

Re, R., Pellegrini, N., Proteggente, A., Pannala, A., Yang, M., Rice-Evans, C. 1999. Antioxidant activity applying an improved ABTS radical cation decolorization assay. Free Radical Bio. Med. 26, 1231-1237.

Reyes-Díaz, M., Meriño-Gergichevich, C., Alarcón, E., Alberdi, M., Horst, W. 2011. Calcium sulfate ameliorates the effect of aluminum toxicity differentially in genotypes of highbush blueberry (Vaccinium corymbosum L.). J. Soil Sci. Plant Nutr. 11, 59-78.

Reyes-Díaz, M., Inostroza-Blancheteau, C., Millaleo, R., Cruces, E., Wulff-Zottele, C., Alberdi, M., Mora, M. L. 2010. Long-term aluminum exposure effects on physiological and biochemical features of highbush blueberry cultivars. J. Amer. Soc. Hort. Sci. 135, 212-222.

Slinkard, K., Singleton, V.L. 1997. Phenol analyses: automation and comparison with manual methods. Am. J. Enol. Viticult. 28, 49-55. 
Starast, M., Karp, K., Vool, E., Paal, T., Albert, T. 2007. Effect of NPK fertilization and elemental sulphur on growth and yield of lowbush blueberry. Agr. Food Sci. 16, 34-45.

Stewart, A.J., Chapman, W., Jenkins, G.I., Graham, I., Martin, T., Crozier, A. 2001. The effect of nitrogen and phosphorus deficiency on flavonol accumulation in plant tissues. Plant Cell Environ. 24, 1189-1197.

Takahashi, T., Ikeda, Y., Nakamura, H., Nanzyo, M. 2006. Efficiency of gypsum application to acid Andosols estimated using aluminum release rates and plant root growth. J Soil Sci. Plant Nutr. 52, 584-592.

Wang, L.J., Shao, H.,L. 2006. Salicylic acidinduced heat or cold tolerance in relation to $\mathrm{Ca}^{2+}$ homeostasis and antioxidant systems in young grape plants. Plant Sci. 170, 685-694.
Yamamoto, Y., Kobayashi, Y., Devi, S.R., Rikiishi, S., Matsumoto, H. 2002. Aluminum toxicity is associated with mitochondrial dysfunction and the production of reactive oxygen species in plant cells. J. Plant Physiol. 128, 63-72.

Yang, W. Q., Goulart, B., Demchak, K. 1996. The effect of aluminum and media on the growth of mycorrhizal and non-mycorrhizal highbush blueberry plantlets. Plant Soil. 183, 301-308.

Yuan, X., Gao, M., Xiao, H., Tan, C., Du, Y. 2012. Free radical scavenging activities and bioactive substances of Jerusalem artichoke (Helianthus tuberosus L.) leaves. Food Chem. 133, 10-14. 